\title{
Three new species of the sea fan genus Leptogorgia (Octocorallia, Gorgoniidae) from the Gulf of California, Mexico
}

\author{
Osvaldo Hernández,2, Jaime Gómez-Gutiérrez², Carlos Sánchez' \\ I Departamento de Ciencias Marinas y Costeras, Universidad Autónoma de Baja California Sur, Carretera al \\ sur km 5.5, CP 23080, La Paz, Baja California Sur, Mexico 2 Departamento de Plancton y Ecología Marina, \\ Centro Interdisciplinario de Ciencias Marinas, Instituto Politécnico Nacional, Av. IPN, s/n, CP 23096, La \\ Paz, Baja California Sur, Mexico \\ Corresponding author: Carlos Sánchez (csanchez@uabcs.mx)
}

Academic editor: J. Reimer | Received 30 January 2020 | Accepted 6 November 2020 | Published 12 February 2021

http://zoobank.org/D6C50910-2C7A-4605-9FAE-B3E25FE48C8A

Citation: Hernández O, Gómez-Gutiérrez J, Sánchez C (2021) Three new species of the sea fan genus Leptogorgia (Octocorallia, Gorgoniidae) from the Gulf of California, Mexico. ZooKeys 1017: 1-20. https://doi.org/10.3897/ zookeys.1017.50619

\begin{abstract}
Three new sea fan species of Leptogorgia were discovered during multiple scuba diving expeditions along the Gulf of California coast and islands. Leptogorgia iridis sp. nov. is distributed in the southern region of the gulf (Mexican Province), inhabiting tropical rocky reefs of the Islas Marías Archipelago (Nayarit) and Bahía Banderas (Jalisco). This species has small colonies $(<7 \mathrm{~cm}$ height) with at least five clearly distinct chromotypes. Leptogorgia martirensis sp. nov. was found exclusively on the rocky reefs of San Pedro Mártir and San Esteban Islands located in the northern region of the Gulf of California (northern region of Cortez Province). Leptogorgia enrici sp. nov. is distributed from the south to the northern region of the Gulf of California (Cortez Province), inhabiting substrates of rocky reefs, sandy and pebbly sea floors. Comprehensive ecological diving expeditions to identify and classify octocorals in the Mexican Pacific (1995-2019) indicate that $L$. iridis sp. nov. and L. martirensis sp. nov. are likely to be micro-endemics and L. enrici sp. nov. is endemic to the Gulf of California, which defines their currently known biogeographic distribution ranges.
\end{abstract}

\section{Keywords}

Alcyonacea, chromotypes, Cnidaria, gorgonians, microendemism, rocky reef

Copyright Osvaldo Hernández et al. This is an open access article distributed under the terms of the Creative Commons Attribution License (CC BY 4.0), which permits unrestricted use, distribution, and reproduction in any medium, provided the original author and source are credited. 


\section{Introduction}

The family Gorgoniidae Lamouroux, 1812 includes mostly species of three genera in the eastern Pacific: Pacifigorgia Bayer, 1951 with anastomosed branching as the main diagnostic character, Eugorgia Verrill, 1868 with the presence of double disk capstans and Leptogorgia Milne Edward \& Haime, 1857; which, in contrast to the previous two genera, does not have a single diagnostic genus morphological feature (Williams et al. 2004; Breedy et al. 2009). Verrill (1868) separated species of the genera Eugorgia from Leptogorgia because Eugorgia species have double disk capstan sclerites. Leptogorgia taxonomic classification is based on several morphological characters that might be present or absent in the genera Pacifigorgia and or Eugorgia (Breedy and Guzman 2002; Breedy et al. 2009). Branching and colony growth patterns and types of sclerites are required morphological diagnostic traits to identify and distinguish among Leptogorgia species (Breedy and Guzman 2007). The lack of a single diagnostic taxonomic character in the genus Leptogorgia causes uncertainties in the taxonomic classification of species in this highly morphologically diverse genus, which currently includes 103 nominal species and seven species assigned as nomen dubium worldwide (Cordeiro et al. 2020). This taxonomical problem is particularly accentuated by multiple species having wide interspecific and intraspecific variability of morphotypes and chromotypes. The molecular evidence strongly suggests that genus Leptogorgia has deep genetic divergence among morphologically similar species, with multiple genetic geographically restricted lineages (Poliseno et al. 2017; Soler-Hurtado et al. 2017a, b; Olvera et al. 2018; Silvestri et al. 2019).

There are 30 extant Leptogorgia species recorded along the American Pacific coast, with Leptogorgia waltonae Olvera, Hernández, Sánchez \& Gómez-Gutiérrez, 2018 being the latest species described in the Mexican Pacific (Olvera et al. 2018). Here we describe three new species of the genus Leptogorgia discovered in the Gulf of California during extensive ecological diving expeditions to identify and classify octocorals in the Mexican Pacific (1995-2019). Therefore, these three new Leptogorgia species increase the total number of nominal Leptogorgia species to 33 for the American Pacific and 20 for the Mexican Pacific.

\section{Materials and methods}

Approximately 500 quantitative monitoring transects, each one covering an area of $30 \mathrm{~m}^{2}$, were surveyed during extensive annual ecological expeditions located along the peninsular coast and at 25 islands of the Gulf of California (1995-2019), Islas Marías Archipelago (2010 and 2018), Bahía Banderas (2013) and Bahía Magdalena (2013-2014) (Fig. 1). Several octocoral colonies were collected during those monitoring surveys for taxonomic purposes. A total of 35 colonies of Leptogorgia iridis sp. nov., 25 colonies of Leptogorgia martirensis sp. nov. and 42 colonies of Leptogorgia enrici sp. nov. were collected during scuba diving between $2-55 \mathrm{~m}$ depths. All 


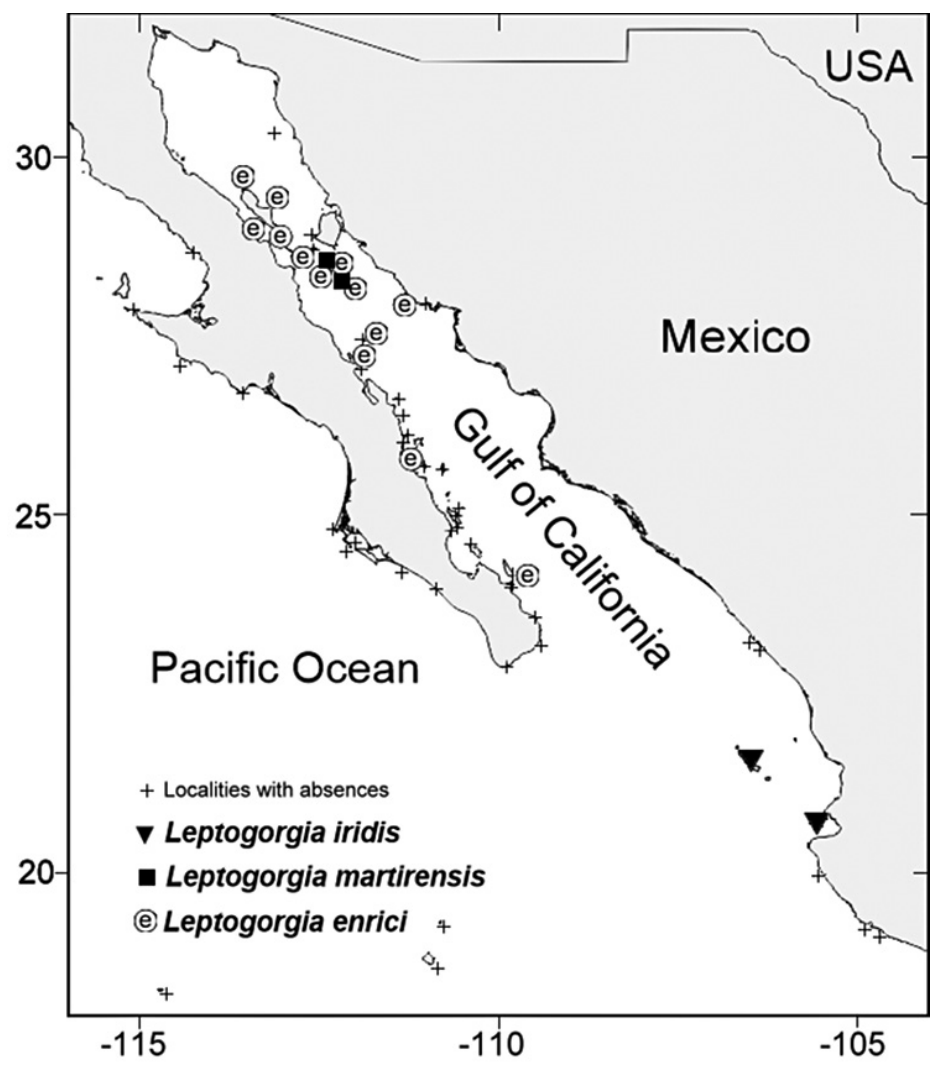

Figure I. Map of the Gulf of California and Mexican Pacific showing collection localities of the three new species of Leptogorgia.

specimens were dried or preserved in $96 \%$ ethanol. A portion of each colony was macerated in sodium hypochlorite to extract the sclerites, washed several times with distilled water and preserved in $96 \%$ ethanol for further microscopic analyses. Sclerites were air-dried and attached to aluminum stubs with double adhesive bands. They were coated with gold using a sputter coater (Polaron E5100) in an argon atmosphere and observed under a Hitachi S-3000 N scanning electron microscopy (SEM) at $20 \mathrm{kV}$. The sclerite morphological traits were compared with sclerites of fourteen nominal Leptogorgia species distributed along the tropical eastern Pacific (Table 1) using original taxonomic descriptions (Breedy and Guzman 2007; Horvath 2011; Breedy et al. 2012; Olvera et al. 2018) and taxonomical analyses from octocoral specimens from the institutional collection of Universidad Autónoma de Baja California Sur (Proyecto Fauna Arrecifal: PFA). Species identification and morphological comparisons among Leptogorgia species were assessed following the standard techniques and nomenclature used by Verrill (1868), Breedy and Guzman (2007), Breedy et al. (2009, 2012), and Horvath (2011) (Table 1). We used standard taxonomic terminology and criteria to describe the three new species (Bayer et al. 


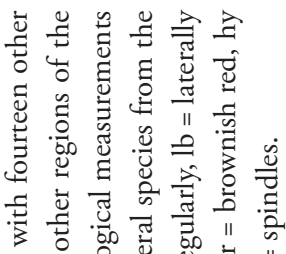

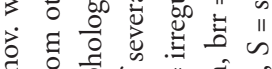
व. के

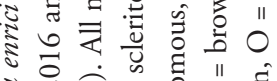

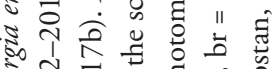

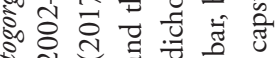

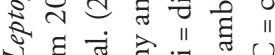
ป हूँ

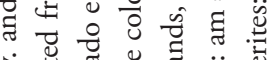

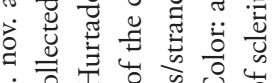

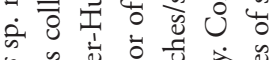

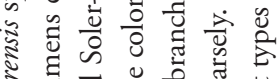
苞 के

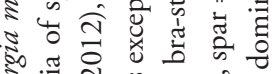

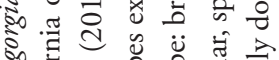

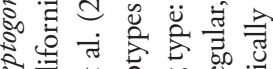

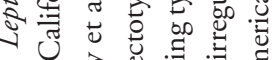

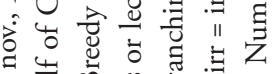

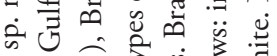

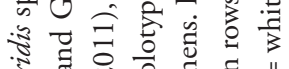

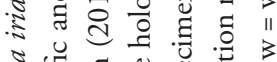

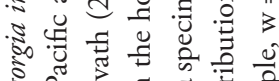

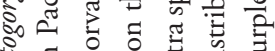

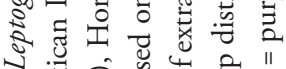

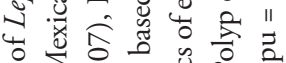

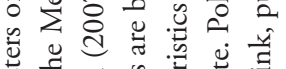

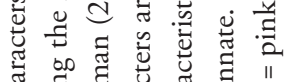
ป⿱艹兀

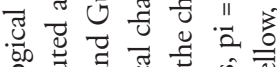

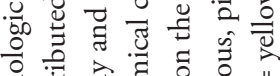

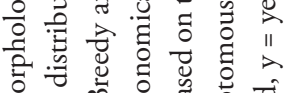

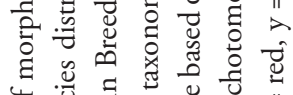

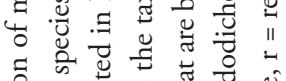
की के

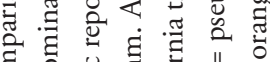

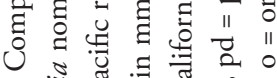
- 50 . -

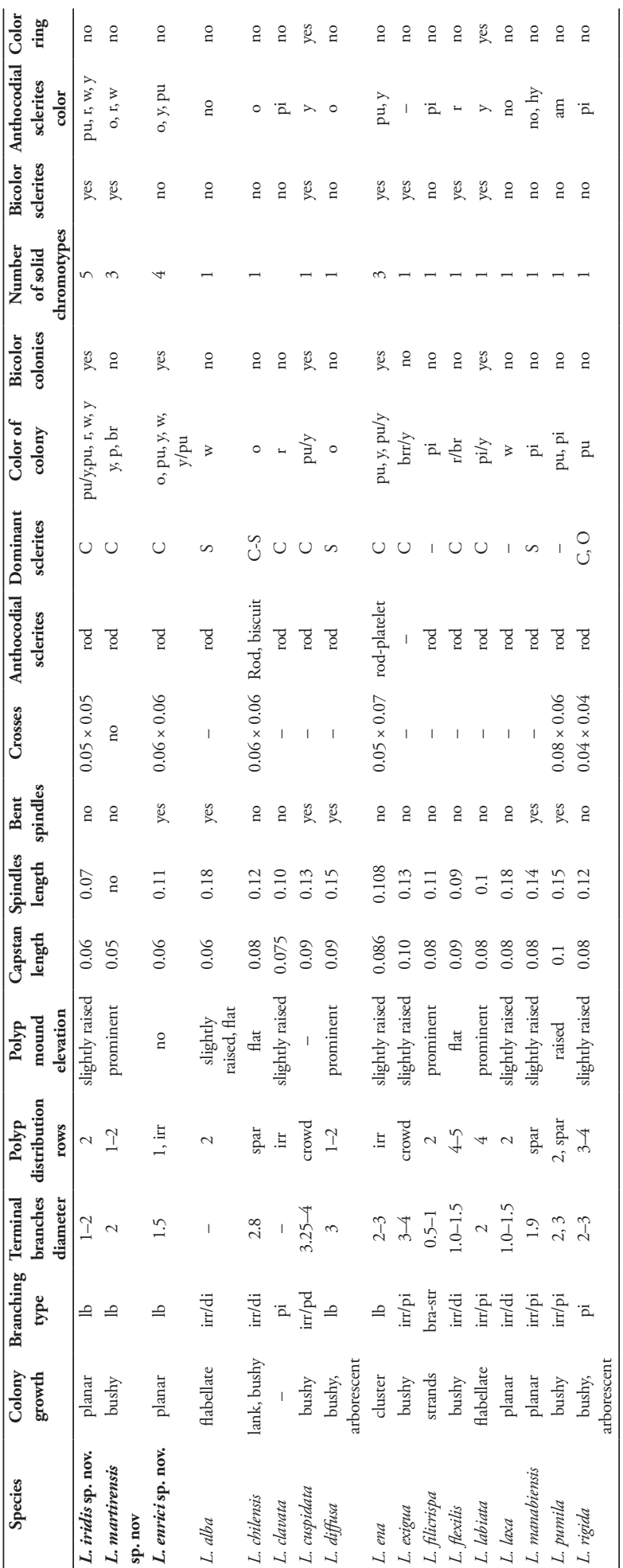


1983; Calvo and Breedy 2002; Breedy et al. 2009, 2013; Breedy and Guzmán 2007, 2013). All the holotypes and paratypes were deposited in the Smithsonian National Museum of Natural History (NMNH).

\section{Systematics}

Class Anthozoa Ehrenberg, 1834

Subclass Octocorallia Haeckel, 1866

Order Alcyonacea Lamouroux, 1812

Suborder Holaxonia Studer, 1887

Family Gorgoniidae Lamouroux, 1812

Genus Leptogorgia Milne Edward \& Haime, 1857

\section{Leptogorgia iridis sp. nov.}

http://zoobank.org/38587E54-6E24-4949-BCF5-61FBB2982023

Figures 3, 8A, B

Material examined. Holotype. NMNH-1638551: dry María Magdalena Island (south west rocky point), Islas Marías Archipelago, Nayarit, Mexico $\left(21^{\circ} 25.267^{\prime} \mathrm{N}\right.$, $\left.-106^{\circ} 24.900^{\prime} \mathrm{W}\right), 10 \mathrm{~m}$ depth, 15 November 2010, collector Carlos Sánchez. Paratypes. NMNH-1638552: dry María Madre Island (southern rocky point), Islas Marías Archipelago, Nayarit, Mexico $\left(21^{\circ} 32.391^{\prime} \mathrm{N},-106^{\circ} 31.877^{\prime} \mathrm{W}\right), 8 \mathrm{~m}$ depth, 18 November 2010, collector Carlos Sánchez. NMNH-1638553: dry María Madre Island (southwest rocky point, Islas Marías Archipelago, Nayarit, Mexico $\left(21^{\circ} 32.391^{\prime} \mathrm{N}\right.$, $\left.-106^{\circ} 31.877^{\prime} \mathrm{W}\right), 8 \mathrm{~m}$ depth, 18 November 2010 , two colonies connected by single holdfast, collector Carlos Sánchez. NMNH-1638554: dry, María Madre Island (southwest rocky point), Islas Marías Archipelago, Nayarit, Mexico $\left(21^{\circ} 25.267^{\prime} \mathrm{N}\right.$, $\left.-106^{\circ} 24.900^{\prime} \mathrm{W}\right), 10 \mathrm{~m}$ depth, 15 November 2010, collector Carlos Sánchez. NMNH1638555: dry colony from El Faro de Cabo Corrientes, Bahía Banderas, Jalisco, Mexico $\left(20^{\circ} 24.553^{\prime} \mathrm{N},-105^{\circ} 41.708^{\prime} \mathrm{W}\right), 2013$, collector Carlos Sánchez.

Type locality. Islas Marías Archipelago is located in the southern region of the Gulf of California, Mexico $\left(21^{\circ} 25.267^{\prime} \mathrm{N},-106^{\circ} 24.900^{\prime} \mathrm{W}\right)$ near the continental shelfbreak about $158 \mathrm{~km}$ southwest of Mazatlán, Sinaloa and $106 \mathrm{~km}$ northwest of Bahía Banderas, Nayarit (Fig. 1).

Holotype colony description. Colony shows lateral branching and planar growth of $7 \mathrm{~cm}$ height and $8.1 \mathrm{~cm}$ width. Holdfast is $5 \mathrm{~mm}$ diameter and arises the main steam $2.1 \mathrm{~cm}$ length and $2 \mathrm{~mm}$ diameter, subdividing into two main branches (Fig. 2A). The longer branch grows up to $2.8 \mathrm{~cm}$ length and $2 \mathrm{~mm}$ diameter before dividing into secondary and further branches $1-2 \mathrm{~mm}$ in diameter. The smaller branches are $4 \mathrm{~mm}$ length and $1 \mathrm{~mm}$ diameter before subdividing and growing downward. The main stem shows three alternating and broken pinnula with a brownish nude axis of $0.5 \mathrm{~mm}$ diameter. Secondary and terminal twigs have blunt tips arising at $45^{\circ}$ angles and of $>2 \mathrm{~mm}$ 

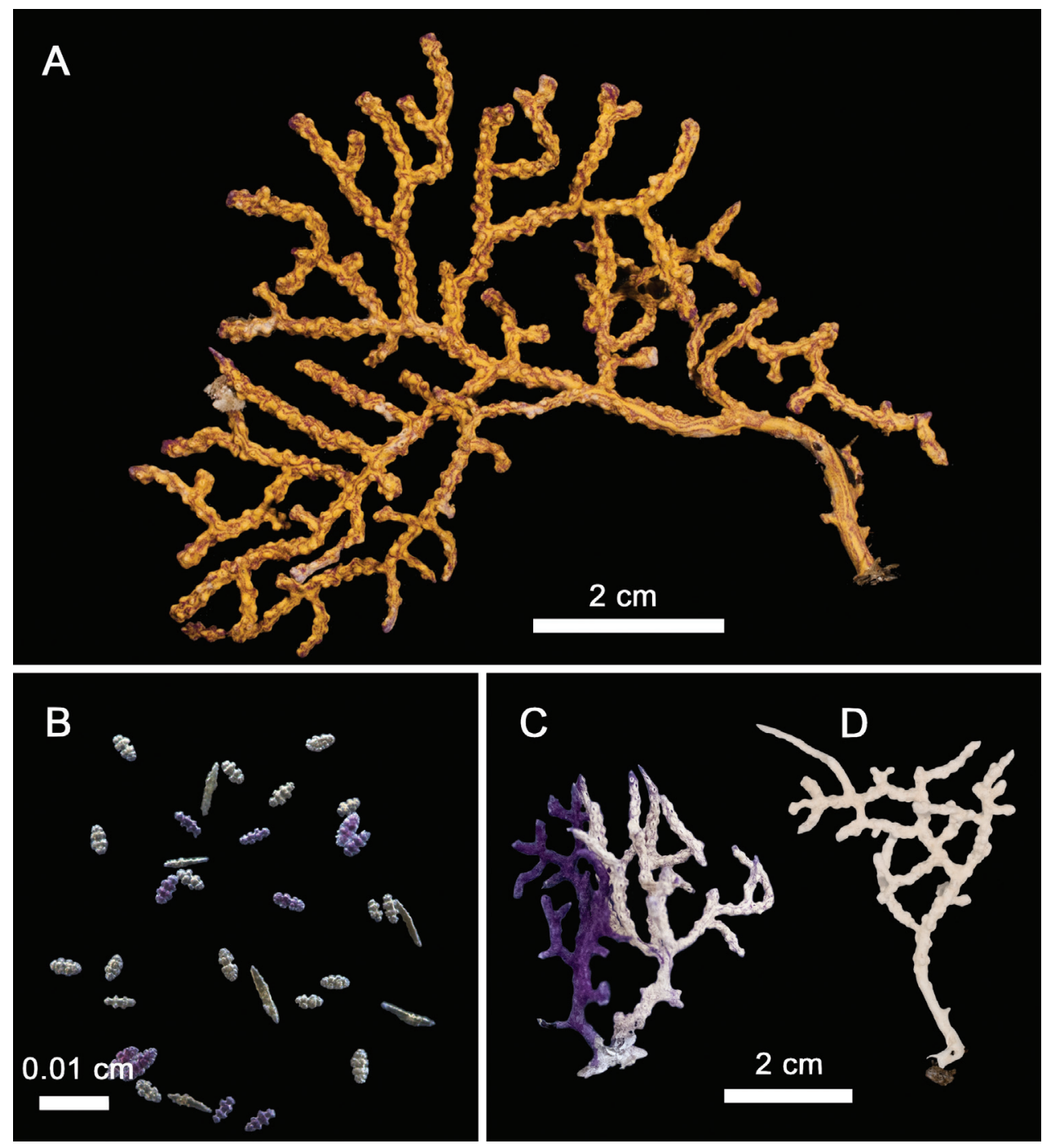

Figure 2. Leptogorgia iridis sp. nov. A holotype NMNH-1638551 B holotype anthocodial and coenenchymal sclerites $\mathbf{C}$ paratype NMNH-1638553, two colonies with different color connected with a single holdfast D paratype NMNH-1638554, monochromatic white chromotype.

diameter. The entire colony is yellow and deep purple, forming longitudinal bicolor striped patterns along the branches from the base to the tips of the colony (Fig. 2A). Polyp mounds are oval $1.0 \times 0.5 \mathrm{~mm}$, slightly raised by $1 \mathrm{~mm}$ with polyp rings, arranged in two rows along with the entire colony, except on the lower half of the stem.

Holotype sclerites. Coenenchymal sclerites of Leptogorgia iridis sp. nov. holotype are mostly bright yellow or purple and few of them are bicolor or white (Fig. 2B). Dominant sclerites are capstans $(0.06 \mathrm{~mm}$ length and $0.04 \mathrm{~mm}$ width) (Fig. 3A). Spindles are scarce $(0.07 \mathrm{~mm}$ length and $0.03 \mathrm{~mm}$ width), slightly tuberculate, of white color with pale orange in the middle (Fig. 3B). Crosses measure up to $0.05 \mathrm{~mm}$ 


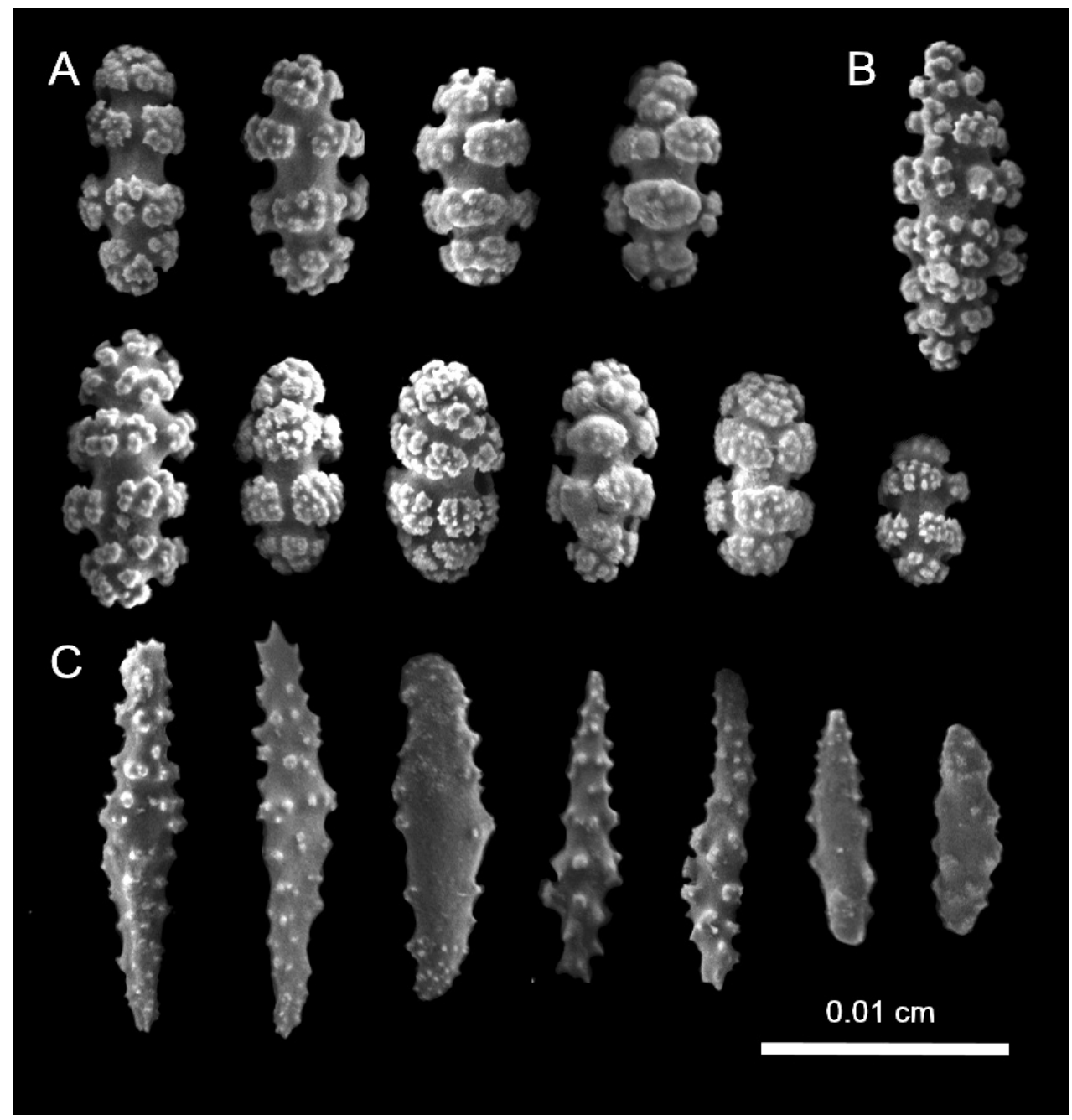

Figure 3. Leptogorgia iridis sp. nov., Scanning Electron Microscopy images of coenenchymal sclerites from the holotype NMNH-1638551 A capstans B spindle $\mathbf{C}$ anthocodial rod sclerites.

length and $0.05 \mathrm{~mm}$ width. Anthocodial sclerites are long rods of $<0.1 \mathrm{~mm}$ length and $0.02 \mathrm{~mm}$ width with acute ends and lobed margins (Fig. 3C).

Morphological variations. Leptogorgia iridis sp. nov. paratypes differ from the holotype in branch diameter and coloration. The morphotypes have a wide range of colorations due to the different proportion of sclerite colors and coenenchymal sclerite arrangement (Figs 2A-D, 8A, B). There are four solid sclerite colorations: yellow, red, purple, and white or with a gradient of colorations among them, including bicolor chromotypes. A colony may have one or two sclerite colors, but their proportion and combination may create different patterns in the colony's appearance. The holotype has yellow and purple sclerites with a longitudinal color arrangement giving the colony a bicolor (yellow and purple) appearance (Fig. 2A, B). The paratype NMNH-1638553 also 
has a mixing of sclerites, one colony has the major sclerite proportion of purple compared to white, and the other colony has a major proportion of white compared to purple sclerites, and both colonies have a scrambled sclerite arrangement giving the colonies their coloration (Fig. 2C). However, in several specimens, such as paratype NMNH1638554, the colony and sclerite coloration is white (Fig. 2D). Colony growth forms of $L$. iridis sp. nov. have relatively low variability. The only different morphotype, so far collected exclusively at Bahía Banderas, Jalisco, were colonies with similar coloration patterns to the holotype, but with relatively thicker branches (up to $4 \mathrm{~mm}$ diameter).

Diagnosis. Purple and red Leptogorgia iridis sp. nov. have quite similar colony shapes. Both L. iridis sp. nov. chromotypes resemble the color of Leptogorgia obscura Bielschowsky, 1929 and Leptogorgia parva Bielschowsky, 1929. However, L. obscura has small anthocodial rods with blunt ends and $L$. parva has anthocodial rods with conspicuous lobed margins, which are absent in L. iridis sp. nov. Additionally, L. obscura and $L$. parva have only one known chromotype, and their terminal branches have acutely pointed ends. In contrast, $L$. iridis sp. nov., has long anthocodial rods with acute ends and no lobed margins, showing up to five solid colony chromotypes and terminal branches with blunt ends.

Habitat and distribution. The distribution of Leptogorgia iridis sp. nov. covers part of the Central Tropical Mexican Pacific (Mexican Province in Brusca and Wallerstein 1979 and Hasting 2000) from Bahía Banderas, Jalisco to Islas Marías Archipelago Nayarit, Mexico (Fig. 2). Leptogorgia iridis sp. nov. grows on shallow rocky reefs $<20 \mathrm{~m}$ depth. Purple colonies were mostly observed in shallow waters $<5 \mathrm{~m}$ depth, the bicolor colonies mostly at 7-8 m depth, and yellow colonies mostly observed at 10-20 m depth. Leptogorgia iridis sp. nov. shares habitat with Leptogorgia ena Breedy, Abeytia \& Guzman, 2012, Leptogorgia rigida Verrill, 1864, Leptogorgia alba (Duchassaing \& Michelotti, 1864), Pacifigorgia arenata (Valenciennes, 1846), Pacifigorgia agassizii (Verrill, 1864), Pacifigorgia media (Verrill, 1864), Pacifigorgia stenobrochis (Valenciennes, 1846), Muricea austera Verrill, 1869, and Heterogorgia papillosa Verrill, 1870.

Etymology. Leptogorgia iridis sp. nov. is named from the Latin word iridis, which means "rainbow" due to the large number of chromotypes observed in the colonies. Large numbers of chromotypes are one of the main diagnostic characteristics of this novel tropical species.

\section{Leptogorgia martirensis sp. nov.}

http://zoobank.org/2F4C8356-9EF8-4772-A607-CBCC74032DB8

Figures 1, 4, 5, 8C, D

Material examined. Holotype. NMNH-1638556: dry, Cueva Refugio, San Pedro Mártir Island, Sonora, Mexico $\left(28^{\circ} 22.297^{\prime} \mathrm{N},-112^{\circ} 19.040^{\prime} \mathrm{W}\right), 1 \mathrm{~m}$ depth, 16 July 2010, collector Carlos Sánchez. Paratypes. NMNH-1638557: dry, Cueva Refugio, San Pedro Mártir Island, Sonora, Mexico $\left(28^{\circ} 22.297^{\prime} \mathrm{N},-112^{\circ} 19.040^{\prime} \mathrm{W}\right), 1 \mathrm{~m}$ depth, 16 July 2010, collector Carlos Sánchez; NMNH-1638558: dry, Cueva Refugio, San 

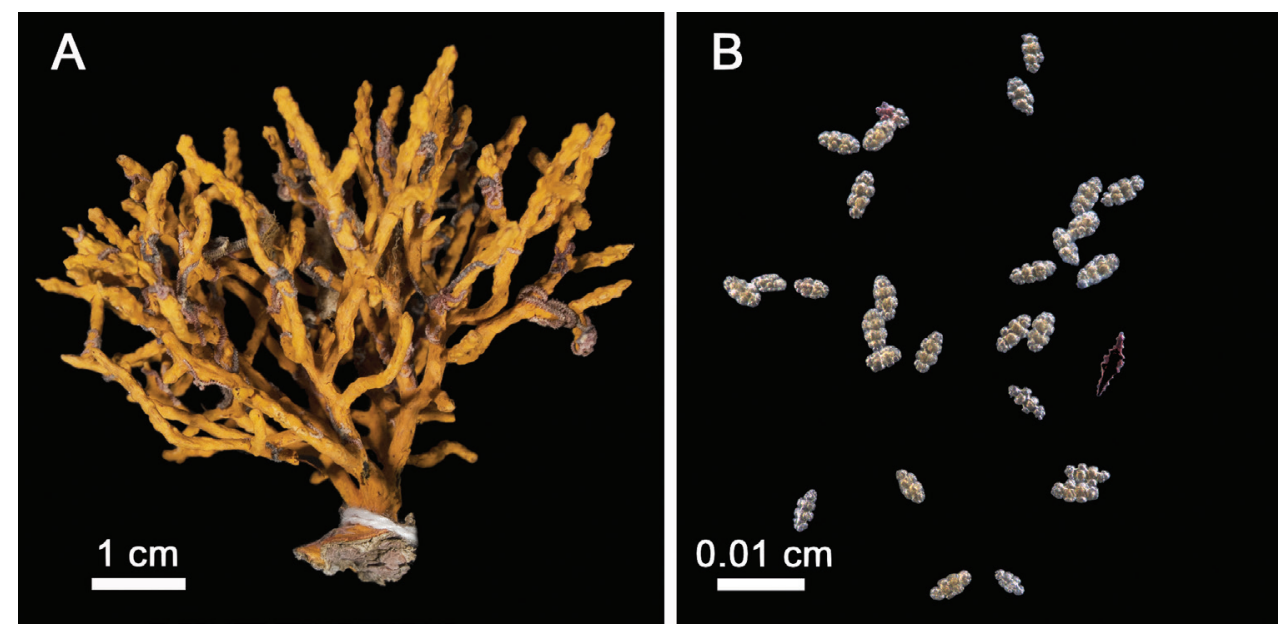

Figure 4. Leptogorgia martirensis sp. nov. A holotype NMNH-1638556 B anthocodial and coenenchymal sclerites.

Pedro Mártir Island, Sonora, Mexico $\left(28^{\circ} 22.297^{\prime} \mathrm{N},-112^{\circ} 19.040^{\prime} \mathrm{W}\right), 1 \mathrm{~m}$ depth, July 16, 2010, collector Carlos Sánchez; NMNH-1638559: San Pedro Mártir Island, Sonora, Mexico $\left(28^{\circ} 22.818^{\prime} \mathrm{N},-112^{\circ} 18.4422^{\prime} \mathrm{W}\right), 20 \mathrm{~m}$ depth, 16 July 2010 , collector Carlos Sánchez.

Type locality. Cueva Refugio, San Pedro Mártir Island, Sonora, Mexico is one of the furthest offshore islands in the Gulf of California (part of midriff islands at the upper Gulf) where volcanic rocky reefs predominate. San Pedro Mártir Island is a UNESCO "Islas del Golfo de California" Biosphere Reserve (Fig. 1).

Holotype colony description. A yellow colony with bushy and dense growth with multiple and irregular brownish lines (Fig. 4A). The colony is $6.1 \mathrm{~cm}$ in length and $8.1 \mathrm{~cm}$ in width. The holdfast is irregular, $14 \mathrm{~mm} \times 11 \mathrm{~mm}$ from which the short main stem rises ( $2 \mathrm{~mm}$ length, $4 \mathrm{~mm}$ diameter). The colony has four main branches up to $11 \mathrm{~mm}$ length and $3 \mathrm{~mm}$ diameter. The main branches subdivide into multiple secondary branches (up to $31 \mathrm{~mm}$ length, $2 \mathrm{~mm}$ diameter). Terminal twigs are flat and short (12 mm length, $2 \mathrm{~mm}$ width) with acute ends. The general pattern of upward ramification is lateral at $45^{\circ}$ angle. Polyp mounds are oval and prominent, forming one or two rows at each side of the branches with $0.5 \mathrm{~mm}$ height, $2 \mathrm{~mm}$ length, and $1 \mathrm{~mm}$ width with elongated calyces. The colony has several specimens of unidentified dried ophiuroids ( $<2 \mathrm{~mm}$ oral disc diameter) attached to the branches (Fig. 4A).

Holotype sclerites. The coenenchymal sclerites are exclusively capstans (Figs 4B, 5A). There is no evidence of other types of sclerites being present in any other section of the colony. The capstans reach $0.05 \mathrm{~mm}$ long and $0.03 \mathrm{~mm}$ wide (Fig. 5A), their color is pale yellow, pink, red or bicolor yellow-red, but the predominant color is pale yellow $(90 \%)$. The anthocodial sclerites are lobed rods with acute or blunt ends up to $0.1 \mathrm{~mm}$ length and $0.03 \mathrm{~mm}$ width in the center (Fig. 5B, C). They are bicolor white-red, red, orange or white. The red chromotype is predominant (70\% of observed colonies) (Fig. 4B). 


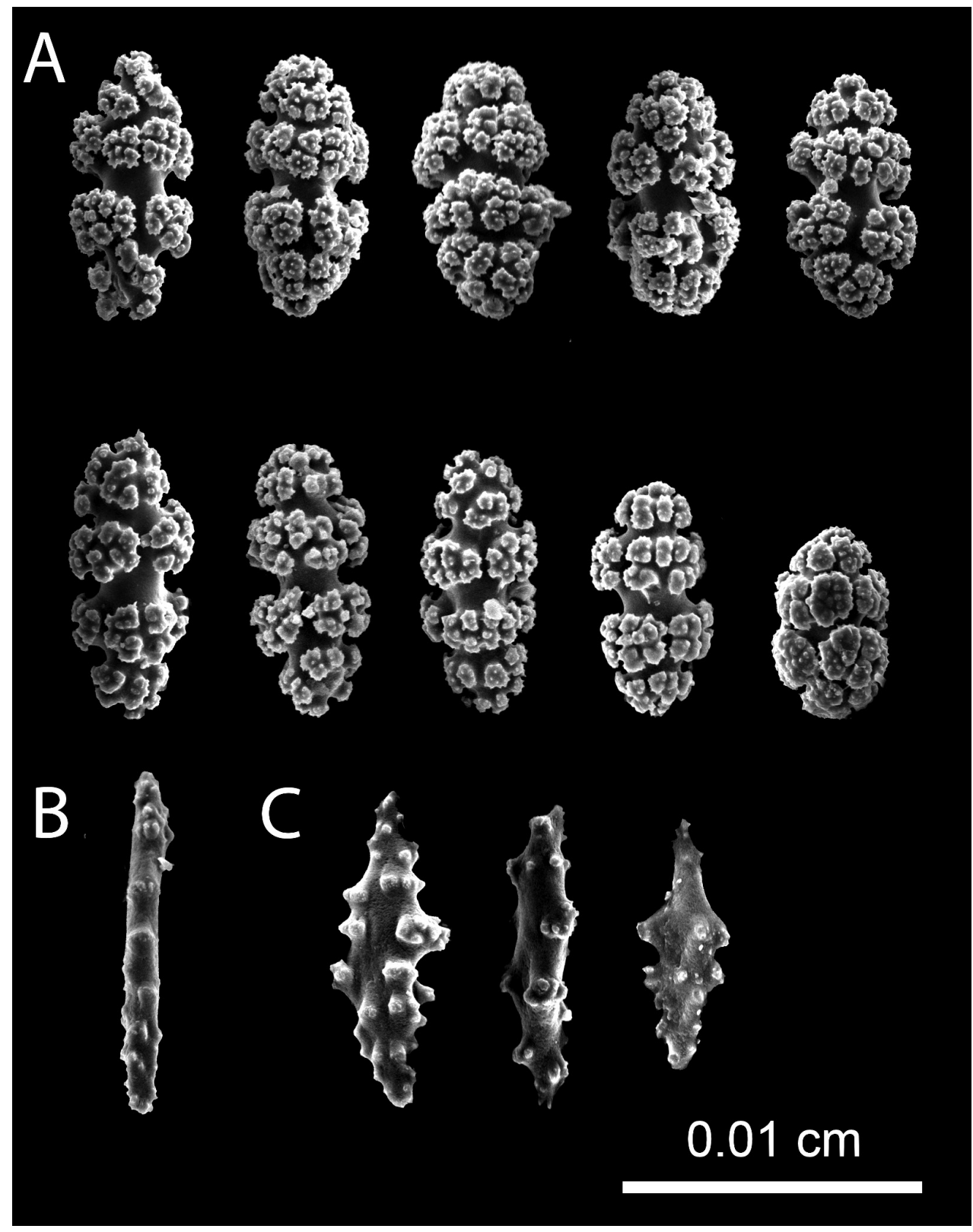

Figure 5. Leptogorgia martirensis sp. nov., Scanning Electron Microscopy images of coenenchymal sclerites from the holotype NMNH-1638556 A capstans B rod lateral view $\mathbf{C}$ anthocodial rod sclerites.

Morphological variations. Leptogorgia martirensis sp. nov. colonies show three chromotypes: purple, yellow and brown (Figs 4A, 8C, D). The colony color depends on the proportion of the dominant color of the coenenchymal sclerites, but in a few cases the colonies show a brown chromotype when the color proportion of sclerites is approximately $50 \%$ purple and $50 \%$ yellow. 
Diagnosis. The colony growth, size and polyp mounds of Leptogorgia martirensis sp. nov. are similar to those of Leptogorgia aequatorialis Bielschowsky, 1929, Leptogorgia obscura and Leptogorgia parva. However, these three species each have only one chromotype (purple, pink, and orange, respectively), and all these species have spindles in their coenenchyme up to $0.1 \mathrm{~mm}$ length, while $L$. martirensis sp. nov. has three chromotypes and no spindles in the coenenchyme.

Habitat and distribution. The micro-endemic Leptogorgia martirensis sp. nov. is only recorded in rocky shallow waters (up to $10 \mathrm{~m}$ depth), and low abundance, at San Pedro Mártir and San Esteban Islands, Sonora. The islands are located in the northern Gulf of California (as part of the Cortez Province according to Brusca and Wallerstein 1979, Hasting 2000), and are the most isolated islands in the gulf (Fig. 1). The Cortez Province is associated with the lowest winter sea superficial temperature (SST $15^{\circ} \mathrm{C}$ ), the widest annual range of SST $\left(15-30^{\circ} \mathrm{C}\right)$, high marine productivity, and harbor a unique macroinvertebrate community, dominated by endemic octocorals of the genus Muricea (Ulate et al. 2016). Leptogorgia martirensis sp. nov. shares its habitat with Muricea austera Verrill, 1869, Muricea plantaginea (Valenciennes, 1846), Muricea spp., Psammogorgia teres Verrill, 1868, and Eugorgia excelsa Verrill, 1868.

Etymology. Leptogorgia martirensis sp. nov. takes its name from the collection site San Pedro Mártir Island.

\section{Leptogorgia enrici sp. nov.}

http://zoobank.org/A3DE39AC-113D-436E-834B-4084F5B6F44F

Figures 1, 6, 7, 8E-G

Material examined. Holotype. NMNH-1638560: dry, San Esteban Island (northwest rocky point), Sonora, Mexico (28 $\left.43.564^{\prime} \mathrm{N},-112^{\circ} 36.799^{\prime} \mathrm{W}\right), 24 \mathrm{~m}$ depth, in situ temperature $19{ }^{\circ} \mathrm{C}, 01$ November 1999, collector Carlos Sánchez. Paratypes. NMNH-1638561: dry, San Esteban Island (northwest rocky point), Sonora, Mexico $\left(28^{\circ} 43.564^{\prime} \mathrm{N},-112^{\circ} 36.799^{\prime} \mathrm{W}\right), 24 \mathrm{~m}$ depth, in situ temperature $19^{\circ} \mathrm{C}, 01$ November 1999, collector Carlos Sánchez; NMNH-1638562: dry, San Esteban Island (northwest rocky point), Sonora, Mexico (28 $\left.43.564^{\prime} \mathrm{N},-112^{\circ} 36.799^{\prime} \mathrm{W}\right), 24 \mathrm{~m}$ depth, in situ temperature $19^{\circ} \mathrm{C}, 03$ November 1999, collector Carlos Sánchez; NMNH-1638563: dry, San Pedro Nolasco Island (south rocky point), Sonora, Mexico (27\%57.094'N, $\left.-111^{\circ} 22.001^{\prime} \mathrm{W}\right), 30 \mathrm{~m}$ depth, 20 October 1999, collector Carlos Sánchez.

Type locality. San Esteban Island is part of the midriff islands at the upper Gulf of California, and is the $15^{\text {th }}$ largest island in Mexico by area $\left(40 \mathrm{~km}^{2}\right)$, and has predominantly volcanic rocky reefs. San Esteban Island is a UNESCO "Islas del Golfo de California" Biosphere Reserve (Fig. 1)

Holotype colony description. A bright yellow colony with planar growth and lateral branching (Fig. 6A, B). The colony is $15.3 \mathrm{~cm}$ high and $115 \mathrm{~cm}$ wide. The colony has a $9 \mathrm{~mm}$ diameter holdfast attached to a rock of small size $(14 \mathrm{~mm} \times 11 \mathrm{~mm})$ of biogenic origin from which emerges the main stem of $15 \mathrm{~mm}$ length and $2 \mathrm{~mm}$ diameter. The stem has longitudinal grooves. From the stem arise two main branches: one of 


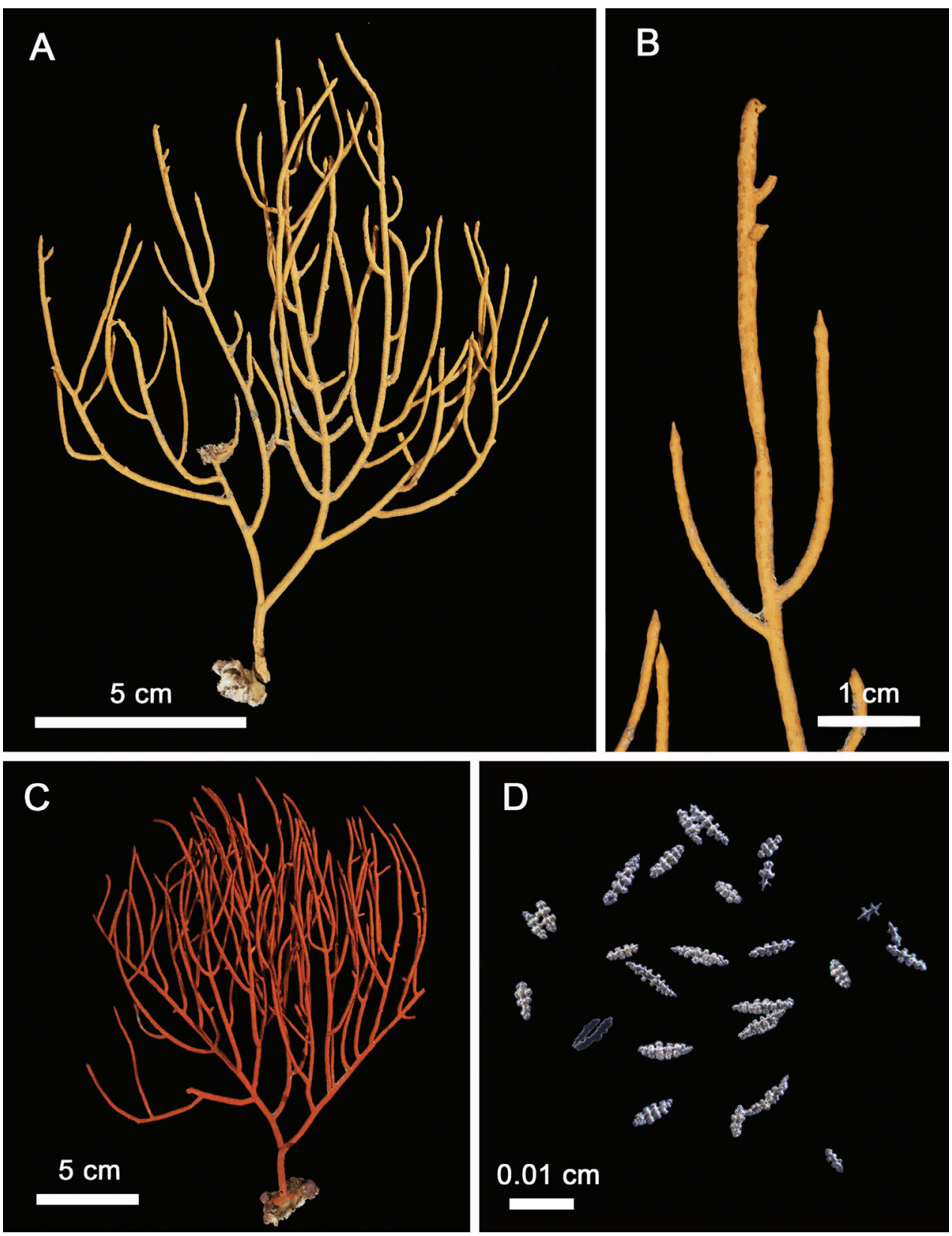

Figure 6. Leptogorgia enrici sp. nov. A holotype NMNH-1638560 B close up of terminal twig C orange chromotype colony $\mathbf{D}$ anthocodial and coenenchymal sclerites.

$35 \mathrm{~mm}$ length and $2 \mathrm{~mm}$ diameter and the other of $117 \mathrm{~mm}$ length and $2 \mathrm{~mm}$ diameter. From these branches arise multiple secondary laterally growing branches. The terminal branches measure 20-30 mm long, $1.5 \mathrm{~mm}$ diameter, and have sharp points (Fig. 6B). The polyp mounds are oval of $1 \mathrm{~mm}$ length and $0.5 \mathrm{~mm}$ width. Mounds are 


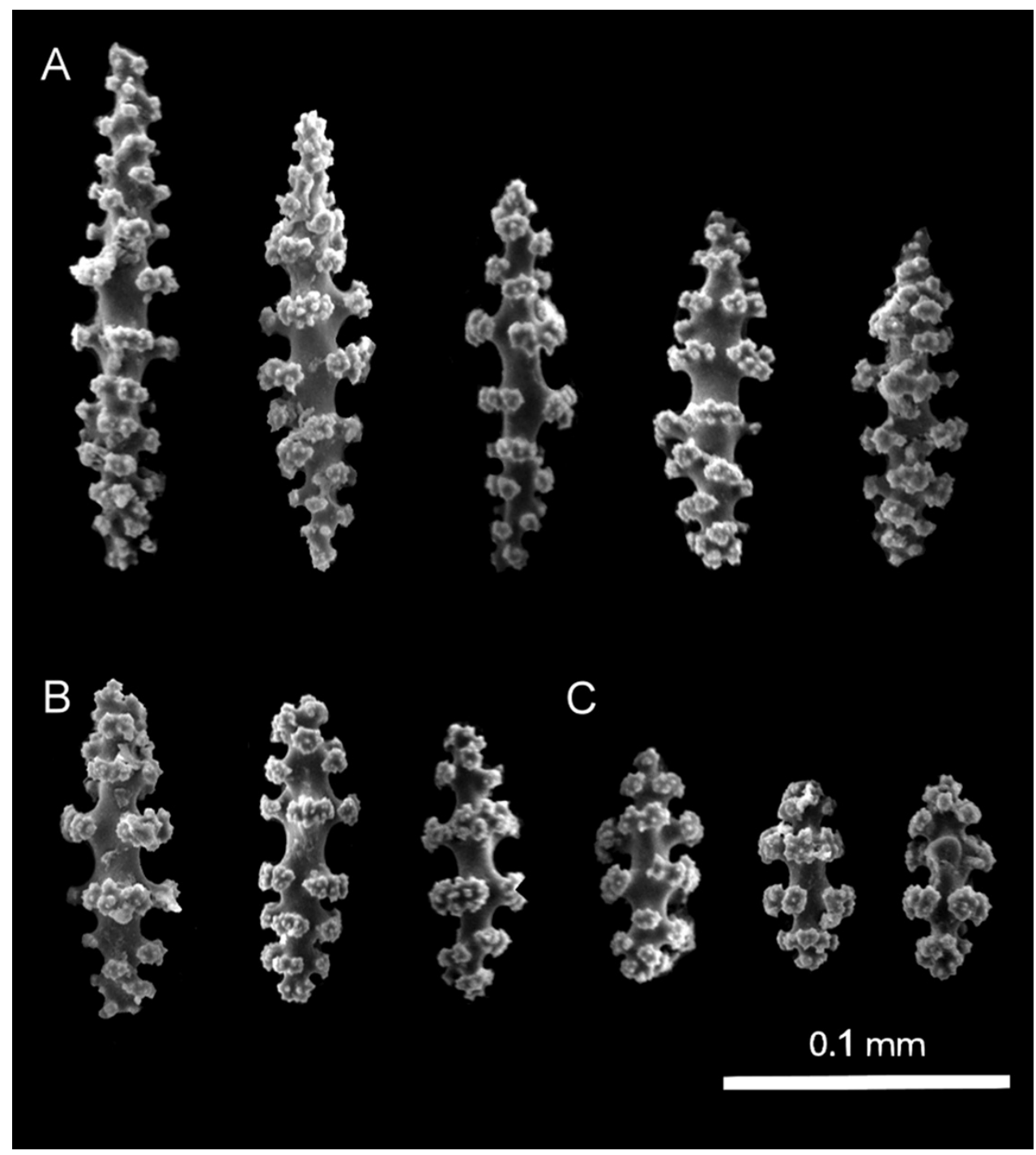

Figure 7. Leptogorgia enrici sp. nov., Scanning Electron Microscopy images of coenenchymal sclerites from the holotype NMNH-1638560 A acute spindles B dull spindles $\mathbf{C}$ capstans.

slightly evident with no elevation and are arranged irregularly or in rows on each side of all branches but not the stem.

Holotype sclerites. The dominant type of sclerites is capstans of $0.06 \mathrm{~mm}$ length and $0.03 \mathrm{~mm}$ width (Fig. 7C). There are abundant long spindles up to $0.11 \mathrm{~mm}$ long and $0.02 \mathrm{~mm}$ thick, which may or may not be slightly curved at the tips (Fig. 7A, B). Crosses are unusual, of $0.06 \mathrm{~mm} \times 0.06 \mathrm{~mm}$ diameter (not shown). Anthocodial sclerites are mostly small yellow rods of up to $0.05 \mathrm{~mm}$ length and $0.01 \mathrm{~mm}$ width, these anthocodial sclerites have smooth edges and blunt tips (Fig. 6D). Long rods are also present, but in considerably low proportion. 

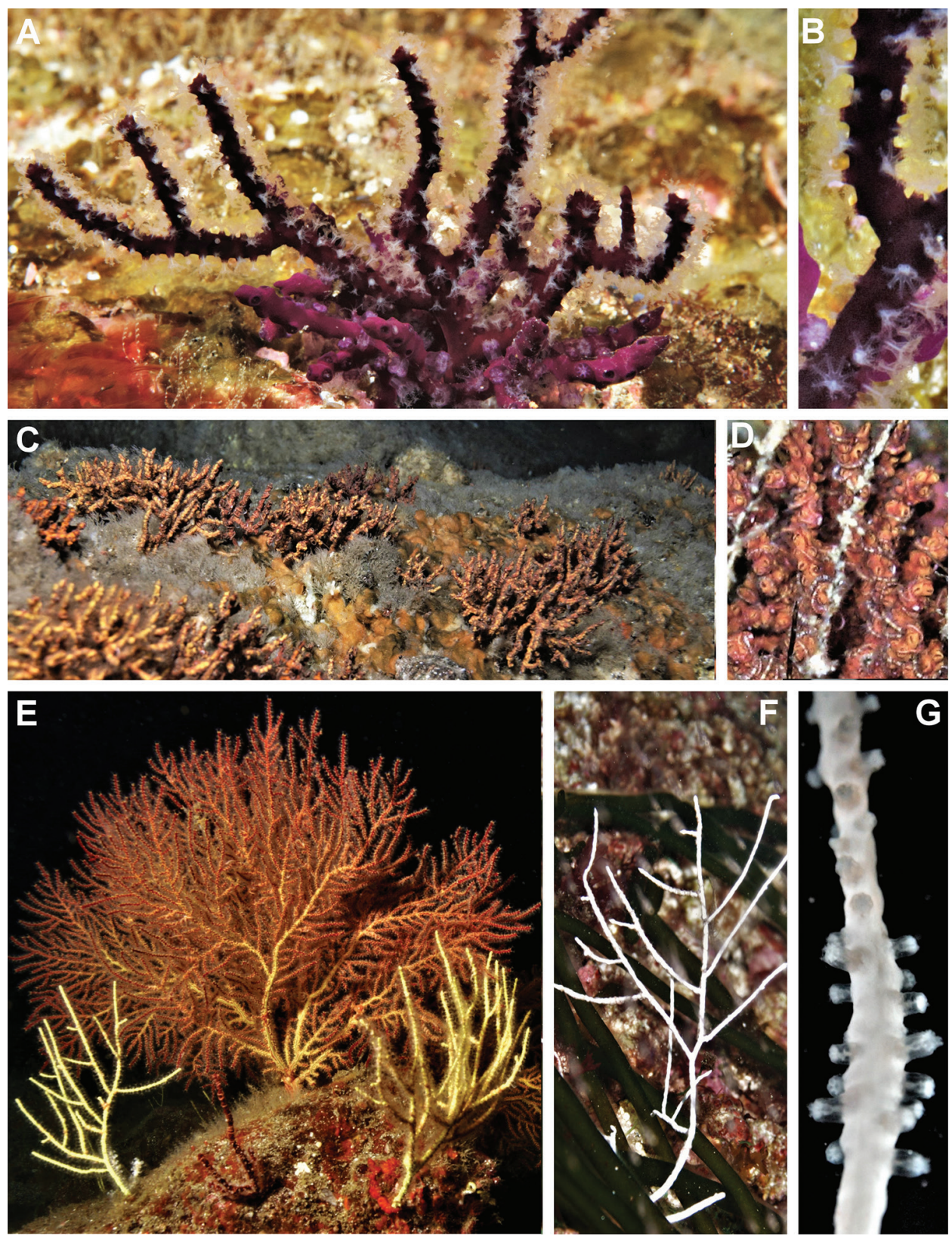

Figure 8. Three new species of sea fans, colonies in situ, underwater images $\mathbf{A}$ Leptogorgia iridis sp. nov., San Juanito Island, Piedra El Morro, Islas Marías Archipelago, $10 \mathrm{~m}$ depth, 23 November 2010, a deep purple colony, at the base a small red wine colony of Leptogorgia ena B Leptogorgia iridis sp. nov., polyps close up C Leptogorgia martirensis sp. nov., Cueva Refugio, San Pedro Mártir Island, Sonora, 2-3 m depth, 16 July 2010 into the cave several small colonies D Leptogorgia martirensis sp. nov., colony close up E Leptogorgia enrici sp. nov., Los Choros, BC, 25 m depth, 10 July 2009, two yellow colonies, a large colony of Eugorgia multifida in the background $\mathbf{F}$ Leptogorgia enrici sp. nov., El Bajo Sur, Cerralvo Island, BCS, $30 \mathrm{~m}$ depth, 23 June 2006, white colony G Leptogorgia enrici sp. nov., polyps close up. Photographs by Carlos Sánchez. 
Morphological variations. Leptogorgia enrici sp. nov. has arborescent and planar forms of colony growth. The planar colony is the more common morphotype. Leptogorgia enrici sp. nov. has four solid colony colorations: yellow (Figs 6A, B, 8E), orange (Fig. 6C), purple, and white (Fig.8F, G) plus a rare bicolor colony (yellow with purple rings around the calices). The sclerites of the coenenchyme always have the same coloration as the colony.

Diagnosis. The purple chromotype of Leptogorgia enrici sp. nov. is morphologically similar to the thin and planar morphotype of Leptogorgia rigida; however, both species differ completely in the form of their sclerites. The coenenchyme sclerites of L. rigida consist mainly of robust capstans with short waists, double heads and spheres (absent in L. enrici sp. nov.), while the sclerites of L. enrici sp. nov. are mainly thin capstans and long and spindle sclerites; spindles are absent in L. rigida. These two species are distributed in different habitats: L. rigida in shallow areas ( $<10 \mathrm{~m}$ depth) attached to rocky reefs, typically inhabiting areas with strong currents or wave action and even in the cracks of rocks, while L. enrici sp. nov. is found in rocky reefs, sandy or pebble beds at depths usually $<20 \mathrm{~m}$ depth. The morphology of L. enrici sp. nov. is similar in the type of branching and colony color to Leptogorgia chilensis (Verrill, 1868) and Leptogorgia flexilis (Verrill, 1868). However, these three species are distinct because $L$. enrici sp. nov. has colonies with planar growth and four solid chromotypes (yellow, orange, purple and white) and has many long spindles. Leptogorgia chilensis and L. flexilis show arborescent growth typically with branches very close to each other. Each species has a single colony chromotype (L. chilensis is orange and L. flexilis is red) and spindle sclerites are present in low proportions, with blunt tips rather than the long spindles with pointed tips observed in L. enrici sp. nov. The long and acute spindles in L. enrici sp. nov., are only comparable in size to the spindles of Leptogorgia alba and Leptogorgia manabiensis Soler-Hurtado, Megina, Machordom \& López-González, 2017 (Soler-Hurtado et al. 2017b). However, these long spindles are the dominant type in L. alba and L. manabiensis, they are broad with acute ends and crowded tubercles. The dominant type of sclerites of L. enrici sp. nov. are capstans, the spindles are thin with blunt tips and with sparse tubercles. The anthocodial rods of L. alba and L. manabiensis are flat, long and have scalloped margins; while the anthocodial rods of L. enrici sp. nov. are mostly short with lobed margins and blunt tips.

Habitat and distribution. Leptogorgia enrici sp. nov. is endemic to the Gulf of California (Cortez Province according to the biogeographic regions of Brusca and Wallerstein 1979 and Hasting 2000). Leptogorgia enrici sp. nov.'s highest densities are concentrated at the northern Gulf of California (northern Cortez sub-province) (Fig. 1), associated with the lowest winter sea surface temperature (SST, $15^{\circ} \mathrm{C}$ ), the widest annual range of SST $\left(15-30{ }^{\circ} \mathrm{C}\right)$, and high marine productivity (Ulate et al. 2016). Leptogorgia enrici sp. nov. inhabits substrates of rocky reefs, or pebbly and shell seafloor habitats surrounded by sand, in shallow waters (5-40 m depth), but most frequently between 20-40 m. Leptogorgia enrici sp. nov. may also be distributed in deeper waters.

Leptogorgia enrici sp. nov. occurs in low densities scattered on the reefs $(<1$ colony $100 \mathrm{~m}^{2}$ ) and never clustered in several colonies. Marine ecological censuses carried out 
during 2009, 2010 and 2018 showed L. enrici sp. nov. is distributed at the Mid-Rift Archipelago of the Gulf of California (Ángel de la Guarda, Partida, Salsipuedes, Las Ánimas, San Lorenzo, San Esteban, San Pedro Mártir, Tortuga and San Marcos) and at the coast of Baja California peninsula (Los Choros). Leptogorgia enrici sp. nov. has been collected with scuba at $40 \mathrm{~m}$ in the central and southern Gulf of California (Isla Danzante and Isla Cerralvo). Leptogorgia enrici sp. nov. shares its habitat with Muricea spp., Muricea plantaginea (Valenciennes, 1846), Muricea austera Verrill, 1869, Muricea fruticosa Verrill, 1869, Eugorgia aurantiaca (Horn, 1861), Psammogorgia teres Verrill, 1868, and Heterogorgia papillosa Verrill, 1870.

Etymology. Leptogorgia enrici sp. nov. is named in honor of Dr. Enric Sala, a National Geographic Explorer-in-Residence actively engaged in the exploration, research, and science communication to advance ocean conservation. Enric Sala is a passionate enthusiast of marine life and the conservation of Mexican seas who actively collaborates to generate marine biodiversity knowledge. He founded and leads the National Geographic's Pristine Seas project that has conducted 30 expeditions in the world, creating 22 no-take large marine reserve ( -5 million $\mathrm{km}^{2}$ of no-fishing zones).

\section{Discussion}

We discovered three new species of the genus Leptogorgia in the Gulf of California, adding biodiversity information on the Eastern Pacific Ocean. Although sea fans are the most abundant benthic macroinvertebrates in the rocky reefs of the Gulf of California (Ulate et al. 2016), their taxonomic identities and geographic delimitations in the Gulf of California have been historically poorly studied (Hernández 2014). Ten out the 30 nominal Leptogorgia species known for the Eastern Pacific have been described between 2000-2018 (Bayer 2000; Horvath 2011; Breedy et al. 2012; SolerHurtado et al. 2017b; Olvera et al. 2018). Bayer (1981) estimated that about 50\% of the sea fan species distributed in the Eastern Pacific were then unknown. This study helps to lessen the knowledge gap of total species for Leptogorgia via the description of these three new species.

The description of Leptogorgia iridis sp. nov., Leptogorgia martirensis sp. nov. and Leptogorgia enrici sp. nov. increases the number of nominal Leptogorgia species currently known in the Mexican Pacific to 20 (Verrill 1868; Bayer 1981; Breedy and Guzman 2005, 2007; Hovart 2011; Breedy et al. 2012; Olvera et al. 2018). Even though Linnean morphological taxonomy remains an integral approach to describing species, the artificial grouping of the genus "Leptogorgia" will change soon based on mitogenomic molecular evidence that suggests that genus "Leptogorgia" is a polyphyletic taxon with multiples generic geographically restricted lineages (Soler-Hurtado et al. 2017a; Poliseno et al. 2017). The Eastern Pacific "Leptogorgia" species are not the oldest nominal assignation and share an immediate common ancestor with the species included to Eugorgia and Pacifigorgia genera (Soler-Hurtado et al. 2017a; Poliseno et al. 2017). 
The discovery of these three new octocoral species was possible because the highest population density of each species was found in relatively isolated marine areas with exceptionally restricted access (Islas Marías Archipelago was a federal penitentiary) or at isolated offshore islands (San Pedro Mártir Island) with access for general public only through touristic trips. However, those locations do not qualify as pristine habitats and they may already be impacted or will be impacted in the near future. The lack of research effort and the small population size of these three new Leptogorgia species explain why these species have been overlooked at the Islas Marías Archipelago and oceanic islands of the Gulf of California. The lack of knowledge of Leptogorgia enrici sp. nov. is because this species is distributed below 30-40 m deep, often on sandypebble sea floors where previous research efforts has been few. Our quantitative, historical, and systematic invertebrate monitoring program has been, so far, focused on fauna from rocky reefs in $<20 \mathrm{~m}$ depth (Hernández 2014; Ulate et al. 2016; Olvera et al. 2018), thus leaving deeper depths unexplored.

Leptogorgia martirensis sp. nov. has been observed and sampled only from rocky reefs from San Pedro Mártir Island (type locality) and San Esteban Island. We observed this species in low density, and only in cavities or caves formed in the island's rocky reefs. We have been carrying out systematic scuba-diving monitoring during 2008-2019 in at least 50 locations at seven islands located close to San Pedro Mártir, providing strong evidence that, except for San Esteban Island, these islands do not harbor colonies of $L$. martirensis sp. nov. The distribution records of these new species compared with our ecological marine census data at extensive locations along the Pacific coast of Mexico (Breedy and Guzman 2005, 2007; Breedy et al. 2012; Ulate et al. 2016) provide strong evidence that these species are micro-endemic to the Gulf of California. Most islands in the Gulf of California have endemic terrestrial fauna (Álvarez-Castañeda and Ortega-Rubio 2003; Brusca et al. 2005), and this may extend to marine species based on our findings. We show evidence that sea fan micro-endemism also exists in aquatic insular habitats of the Gulf of California, such as Islas Marías Archipelago, San Pedro Mártir and San Esteban Islands, similar to that proposed for the Islas Revillagigedo Archipelago (Olvera et al. 2018).

\section{Acknowledgements}

We thank Octavio Aburto (SIO-UCSD) and Exequiel Ezcurra (UC Riverside) for their facilities for the collection of invertebrates at Islas Marías Archipelago (IMA) during November 2010 and 2016. We thank scientists and crew of the liveaboard "Rocío del Mar" for their valuable help during the scuba diving collection. Instituto Nacional de Ecología (INE), Mexico, Fondo Mexicano and an anonymous donor funded the IMA research cruise. We are grateful for research collection facilities and permission to Secretaría de Medio Ambiente y Recursos Naturales (SEMARNAT) and Comisión Nacional de Áreas Naturales Protegidas (CONANP), Mexico (Oficio 
NUM. F00-0526). We thank Secretaría de Gobernación de México and Secretaría de Marina for their logistic facilities. Universidad Autónoma de Baja California Sur and Centro Interdisciplinario de Ciencias Marinas (Instituto Politécnico Nacional, SIPIPN 2010-2020) provided additional financial support. This research was conducted as part of the Universidad Autónoma de Baja California Sur, Proyecto Fauna Arrecifal (UABCS-PFA). UABCS Fauna Reef Conservation Research Programs is funded by the grants: SEMARNAT-CONACYT 2004-01-445 "Biogeography and molecular systematics of sea fans and soft corals (Cnidaria: Octocorallia) in Mexico's Pacific and the Gulf of California"; CONABIO JF190/2013 "Inventory of sessile marine life in the Pacific islands of Baja California Sur"; UC-MEXUS "An ecological and economic baseline for the Revillagigedo Archipelago Biosphere Reserve, Mexico" (2006), UABCS-SCRIPPS-CBMC “Ecological Monitoring ProMARES”, and Pristine Seas of National Geographic Society (2016). All these research projects were carried out at Revillagigedo Archipelago (2006, 2016), Islas Marías Archipelago (2010), Bahía Banderas (2013), and Gulf of California (1998-2018) expeditions. J.G.-G. is a COFAAIPN, EDI-IPN, and SNI fellow.

\section{References}

Álvarez-Castañeda ST, Ortega-Rubio A (2003) Current status of rodents on islands in the Gulf of California. Biological Conservation 109(2): 157-163. https://doi.org/10.1016/S00063207(02)00121-0

Bayer FM (1981) Status of Knowledge of Octocorals of World Seas. Seminários de Biología Marihna. Academia Brasileira de Ciências, Río de Janeiro, 3-11.

Bayer FM (2000) A new species of Leptogorgia from the eastern Pacific (Coelenterata: Octocorallia: Holaxonia). Proceedings of the Biological Society of Washington 113(3): 609-616.

Bayer FM, Grasshoff M, Verseveldt J (1983) Illustrated Trilingual Glossary of Morphological and Anatomical Terms Applied to Octocorallia. Leiden, 75 pp.

Breedy O, Guzman HM (2002) A revision of the genus Pacifigorgia. Proceedings of the Biological Society of Washington 115(4): 782-839.

Breedy O, Guzman, HM (2007) A revision of the genus Leptogorgia Milne Edwards \& Haime, 1857 (Coelenterata: Octocorallia: Gorgoniidae) in the eastern Pacific. Zootaxa 1419: 1-90. https://doi.org/10.11646/zootaxa.1419.1.1

Breedy O, Guzman HM (2013) A new species of the genus Eugorgia (Cnidaria: Octocorallia: Gorgoniidae) from mesophotic reefs in the eastern Pacific. Bulletin of Marine Science 89(3): 735-743. https://doi.org/10.5343/bms.2013.1014

Breedy O, Abeytia R, Guzman HM (2012) A new species of Leptogorgia (Cnidaria: Anthozoa: Octocorallia) from the mexican Pacific coast. Bulletin of Marine Science 88: 319-325. https://doi.org/10.5343/bms.2011.1103

Breedy O, Guzman HM, Vargas S (2009) A revision of the genus Eugorgia Verrill, 1868 (Coelenterata: Octocorallia: Gorgoniidae). Zootaxa 46: 1-46. 
Breedy O, Williams GC, Guzman HM (2013) Two new species of gorgonian octocorals from the Tropical Eastern Pacific biogeographic region (Cnidaria, Anthozoa, Gorgoniidae). ZooKeys 90: 75-90. https://doi.org/10.3897/zookeys.350.6117

Brusca RC, Wallerstein BR (1979) Zoogeographic pattern of idoteid isopods in the northeast Pacific, with a review of shallow water zoogeography of the area. Bulletin of the Biological Society of Washington 3: 67-105.

Brusca RC, Findley LT, Hastings PA, Hendrickx ME, Torre Cosio J, van der Heiden AM (2005) Macrofaunal diversity in the Gulf of California. In: Cartron, JL, Caballos EG, Felger RS (Eds) Biodiversity, Ecosystems, and Conservation in Northern Mexico. Oxford University Press, Oxford, 179-203.

Calvo A, Breedy O (2002) Glosario tetralingüe de términos aplicados a la morfología y anatomía de Octocorallia (Coelenterata: Anthozoa). Revista de filología y lingüística de la Universidad de Costa Rica 139-158. https://doi.org/10.15517/rfl.v28i2.4493

Cordeiro R, McFadden C, van Ofwegen L, Williams G (2020) World list ofOctocorallia. Leptogorgia Milne Edwards, 1857. http://www.marinespecies.org/aphia.php?p=taxdetailsandid=125302 [Accessed through World Register of Marine Species on 2020-09-01]

Hasting PA (2000) Biogeography of the Tropical Eastern Pacific: distribution and phylogeny of chaenopsid fishes. Zoological Journal of the Linnean Society 128(3): 319-335. https:// doi.org/10.1111/j.1096-3642.2000.tb00166.x

Hernández O (2014) Abanicos de mar del género Leptogorgia (Octocorallia: Gorgoniidae) del Pacífico Mexicano y Golfo de California: Variaciones intraespecíficas y ámbito geográfico. Master Science thesis. Centro Interdisciplinario de Ciencias Marinas, Instituto Politécnico Nacional. La Paz, Baja California Sur, 170 pp.

Horvath EA (2011) An unusual new "sea fan" from the northeastern Pacific Ocean (Cnidaria: Octocorallia: Gorgoniidae). Proceedings of the Biological Society of Washington 124: 45-52. https://doi.org/10.2988/10-27.1

Olvera U, Hernández O, Sánchez C, Gómez-Gutiérrez J (2018) Two new endemic species of Gorgoniidae (Cnidaria, Anthozoa, Octocorallia) from Revillagigedo Archipelago, Mexico. Zootaxa 4442(4): 523-538. https://doi.org/10.11646/zootaxa.4442.4.2

Poliseno A, Feregrino C, Sartoretto S, Aurelle D, Wörheide G, McFadden CS, Vargas S (2017) Comparative mitogenomics, phylogeny and evolutionary history of Leptogorgia (Gorgoniidae). Molecular Phylogenetics and Evolution 115: 181-189. https://doi.org/10.1016/j. ympev.2017.08.001

Silvestri S, Figueroa DF, Hicks D, Figueroa NJ (2019) Mitogenomic phylogenetic analyses of Leptogorgia virgulata and Leptogorgia hebes (Anthozoa: Octocorallia) from the Gulf of Mexico provides insight on Gorgoniidae divergence between Pacific and Atlantic lineages. Ecology and Evolution 9(24): 14114-14129. https://doi.org/10.1002/ ece3.5847

Soler-Hurtado MM, López-González PJ, Machordom A (2017a) Molecular phylogenetic relationships reveal contrasting evolutionary patterns in Gorgoniidae (Octocorallia) in the Eastern Pacific. Molecular Phylogenetics and Evolution 111: 219-230. https://doi. org/10.1016/j.ympev.2017.03.019 
Soler-Hurtado MM, Megina C, Machordom A, López-González PJ (2017b) Foxed intra- and interspecific differentiation in Leptogorgia (Octocorallia: Gorgoniidae). A description of a new species based on multiple sources of evidence. Scientia Marina 81(2): 147-157. https://doi.org/10.3989/scimar.04509.01C

Ulate K, Sánchez C, Sánchez-Rodríguez A, Alonso D, Aburto-Oropeza O, Huato-Soberanis L (2016) Latitudinal regionalization of epibenthic macroinvertebrate communities on rocky reefs in the Gulf of California. Marine Biology Research 12(4): 389-401. https://doi.org/ 10.1080/17451000.2016.1143105

Verrill AE (1868) Notes on Radiata in the Museum of Yale College, Number 6: review of the corals and polyps of the West Coast of America. Transactions of the Connecticut Academy of Arts and Sciences 1: 377-422.

Williams GC, Breedy O (2004) The panamic gorgonian genus Pacifigorgia (Octocorallia: Gorgoniidae) in the Galápagos Archipelago, with descriptions of three new species. Proceedings of the California Academy of Sciences 55(3): 55-88. 